\title{
PLUTONIUM ISOTOPES IN ECOSYSTEM OF A RUNNING SHALLOW LAKE
}

\author{
R. Gvozdaitė, R. Druteikienè, N. Tarasiuk, and N. Špirkauskaitė \\ Institute of Physics, Center for Physical Sciences and Technology, Savanoriu 231, LT-02300 Vilnius, Lithuania \\ E-mail: ruta@ar.fi.lt
}

Received 23 June 2010; revised 6 September 2010; accepted 16 September 2010

\begin{abstract}
The aim of the present work is to get information on the possibilities of the shallow lake self-cleaning from plutonium isotopes using Lake Žuvintas as an object of study. A choice of the object is mainly related to the peculiarity of hydrology and hydrodynamics of Lake Žuvintas located in the southern part of Lithuania that was affected by radioactive fallouts after the nuclear events. During the period of study the bottom sediments of Lake Žuvintas behaved mainly as an accumulator of Pu isotopes. The main part of plutonium of the Chernobyl origin in surface sediments is present in exchangeable and potentially mobile physico-chemical forms. Processes of Pu migration are especially active during winter season when under anaerobic conditions the most important role in the $\mathrm{Pu}$ isotopes transfer belongs to reduced plutonium ions.
\end{abstract}

Keywords: lake, plutonium isotopes, water, sediments, physico-chemical forms

PACS: $28.60 .+\mathrm{s}, 82.80 .-\mathrm{d}, 89.40 . \mathrm{Cc}, 89.60 . \mathrm{Ec}$

\section{Introduction}

Nuclear tests and nuclear accidents, as well as the production of radioactive wastes, make a serious threat to the surrounding terrestrial and aquatic environment. For prediction of the radiation situation, in order to sustain the environmental quality and safety, substantial research efforts have been directed worldwide to elucidate underlying mechanisms responsible for the behaviour of radionuclides.

The Lithuanian territory was contaminated by artificial radionuclides due to the nuclear weapon tests in the atmosphere (especially due to the tests in Novaya Zemlya, the North of Russia) and the Chernobyl NPP accident [1]. It is known that after the radiological accidents the lakes due to global and local fallouts turn into a repository of radionuclides [2], which are mainly accumulated in sediments. With time, due to a number of natural processes related to sediment self-cleaning, such lakes become a long-term secondary source of radionuclides for outflowing brooks and rivers. It is a very urgent problem in Lithuania where almost $1.5 \%$ of the territory is occupied by water bodies (more than 3000 lakes). An estimation of lakes as a potential secondary source of radionuclides is related to the determination of the radionuclide enrichment coefficient - a ratio of annual sums of water-soluble radionuclide activity concentrations in outflowing to those in inflowing rivers.
Such preliminary investigations carried out in Lithuania for radiocesium showed the self-cleaning processes to be most effective in very shallow lakes [3]. However, such information on the self-cleaning processes related to the other radionuclides (especially plutonium $(\mathrm{Pu})$ ) in freshwater lakes is scarce. It is known that Pu behaviour in various environmental systems and also in aquatic systems depends on the geochemical and physical characteristics of the environment. A number of studies have shown that mineralogy, chelating agents, redox conditions, $\mathrm{pH}$, and temperature are able to bring about a significant alteration in the environmental behaviour of plutonium [4-10]. Moreover, plutonium ions often are not in a state of thermodynamic equilibrium in waters and their possibility of their migration is related to the form in which the nuclides are introduced into the aquatic system [11].

Nowadays the investigations of both behaviour and fate of radionuclides in the environmental water systems became relevant because of the potential releases of radionuclides associated with decommissioning of the Ignalina NPP and storage of radioactive wastes [12, 13]. The choice of the object is related to the peculiarity of hydrology and hydrodynamics of Lake Žuvintas that has been affected by radioactive fallouts after both the nuclear weapon tests and the Chernobyl NPP accident [1]. A number of lakes similar to Lake Žuvin- 
tas due to their hydrological characteristics are located in the vicinity of the Ignalina NPP. The comprehensive assessment of the self-cleaning mechanisms of water ecosystem against radionuclides is suggested to be the key for prediction of the radioecological situation in the comparable lakes.

The aim of the present work is to get information on the possibilities of long-term self-cleaning from plutonium isotopes of the running shallow lake. The main focus was concentrated on the physico-chemical forms of plutonium of different derivation.

\section{Object of the study}

Lake Žuvintas $\left(54^{\circ} 28^{\prime} 18^{\prime \prime} \mathrm{N}, 23^{\circ} 38^{\prime} 00^{\prime \prime} \mathrm{E}\right)$ is located in the southern part of Lithuania (Fig. 1). It is a shallow eutrophic lake [14]. According to different authors [14, 15], its mean depth is estimated to be in the range of 0.7-1.0 m, and the maximum depth at 2.5-3.4 m. Žuvintas area $\left(\sim 10.1 \mathrm{~km}^{2}\right)$ is covered by large marshy zones. The lake is surrounded by a number of swamps and its drainage basin is huge $\left(\sim 345 \mathrm{~km}^{2}\right)$. The lake is running. Water debits of the main inflow (the Bambena River) and the outflow (the Dovine River) are estimated to be 1.66 and $2.03 \mathrm{~m}^{3} / \mathrm{s}$, respectively. Notional water retention time of the lake is of the order of $0.11 \mathrm{y}$. However, the main fairway flows connecting the Bambena and Dovine Rivers are located in the west side of the lake. Therefore, the rest part of the lake covered by large areas of marshy zones cannot be treated as a running one. The water level of the lake is controlled by a dam at the Dovine River. Bottom sediments of the lake are of the peat and sapropelic type and are rich in organics (up to 67\%). Density of the surface sediments varies mainly in the range of $55-60 \mathrm{~kg} / \mathrm{m}^{3}$ [2].

Data on radiocesium activity concentrations in sediments in Lake Žuvintas measured in 2000-2001 show them not to exceed $160 \mathrm{~Bq} / \mathrm{kg}$ [2]. Assessments of radiocesium loads in soils of the drainage basin showed them to be of the $2700 \mathrm{~Bq} / \mathrm{m}^{2}$ order. The analysis of radiocesium physico-chemical forms in the surface sediments evidenced its high abilities of remobilization [2]. Investigations showed that 15 years after the Chernobyl accident Lake Žuvintas behaved as a significant secondary source of radiocesium for the Dovine River: the respective mean annual value of the radiocesium enrichment coefficient was estimated to be 2.5 for 2000 2001 [2].

Investigations of the lake thermal regime show that Lake Žuvintas belongs to a "super-warm" type [15]: temperatures of the near-bottom water of the deepest

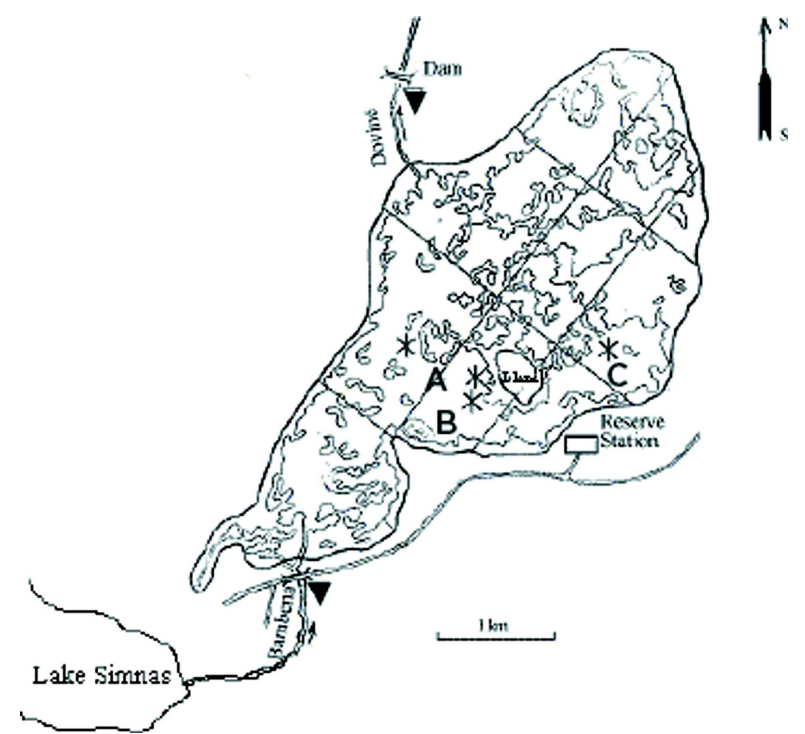

Fig. 1. Scheme of sampling sites in Lake Žuvintas: water $\mathbf{\nabla}$, sediments $(A, B, C)$, and measurement sites of oxygen, $\mathrm{H}_{2} \mathrm{~S}$, and methane.

bottom areas in winter are always above $4{ }^{\circ} \mathrm{C}$. During warm seasons, the water column of the lake is mainly isothermal. It is also mainly oxygenated due to high photosynthetic activity of bottom plants and phytoplankton [16]. However, due to elevated consumption of oxygen related to sediment organics decomposition at high temperatures of the surface sediments, in deep bottom areas, anaerobic conditions can be formed. In winter, anaerobic conditions in the near-bottom water are typical in the deepest areas of the lake. The best oxygenous regime in winter is formed in the fairway due to significant amounts of oxygen transferred to the lake with the inflows of the Bambena River.

\section{Materials and methods}

\subsection{Sampling and analysis}

In Lake Žuvintas 3 sediment cores were taken at the bottom depth of $\sim 2.5 \mathrm{~m}$ in 1999/2000 winter. A bottom sampler (Ekman-Birge type), a light stainless steel tubing of the $20 \mathrm{~cm}$ height and the square cross-section $\left(15 \times 15 \mathrm{~cm}^{2}\right)$ with a spring bottom shutter, operated manually, was used. Sediment cores were sliced into layers of about $2 \mathrm{~cm}$ thickness and, depending on the analysis type, were dried at room temperatures or stored in a refrigerator.

Water samples $(\sim 3001)$ were taken at the inflow to the lake of the Bambena River and at the dam of the Dovine River in winter in 2000/2001 and 2001/2002 and in summer in 2001. With the aim to separate the water-soluble and associated with the suspended 
particulate fractions of radionuclide activity concentrations, water samples were passed through membrane $(0.4 \mu \mathrm{m})$ filters using a vacuum pump system. At the outset, plutonium was radiochemically extracted from the sample, with particular attention given to its separation from ${ }^{241} \mathrm{Am}$, whose $\alpha$-line overlaps with that of ${ }^{238} \mathrm{Pu}$. The ion-exchange chromatography method, enabling extraction of trace amounts of the investigated radionuclides and distinguished for extreme selectivity, was used [17]. A chemical yield of a number of plutonium isotope separation procedures was checked using ${ }^{242} \mathrm{Pu}$ as a tracer. The yield varied in the range of 60-80\%. The sequential extraction method of Tessier [18] was used to study the physico-chemical forms of $\mathrm{Pu}$ isotopes. The ORTEC Octete-Plus $\alpha$-spectrometer with eight $600 \mathrm{~mm}^{2}$ detectors (resolution in the range of $25-27 \mathrm{keV}$; efficiency $20 \%$ ) was used to measure the $\alpha$-activity of plutonium isotopes. Detection limit of ${ }^{239+240} \mathrm{Pu}$ for $\alpha$ counting time of $90000 \mathrm{~s}$ is about $10^{-3} \mathrm{~Bq}$.

\subsection{Estimations of the Pu origin in samples}

The impact of plutonium sources of the global and Chernobyl fallouts on the environment was estimated using a simple set of equations [19]

$$
\begin{aligned}
& A_{239+240 \mathrm{Pu}}=A_{\mathrm{g}}+A_{\mathrm{Ch}}, \\
& A_{238 \mathrm{Pu}}=\zeta A_{\mathrm{g}}+\varepsilon A_{\mathrm{Ch}},
\end{aligned}
$$

where $A_{239+240 \mathrm{Pu}}, A_{238} \mathrm{Pu}$ are measured activity concentrations of $\mathrm{Pu}$ isotopes in the sample, $A_{\mathrm{g}}$ and $A_{\mathrm{Ch}}$ are ${ }^{239+240} \mathrm{Pu}$ activity concentrations caused by the global and Chernobyl fallouts, respectively. $\zeta$ and $\varepsilon$ are activity ratios of ${ }^{238} \mathrm{Pu}$ to ${ }^{239+240} \mathrm{Pu}$ due to the global and Chernobyl fallouts, respectively. The solutions of Eq. (1) are as follows:

$$
\begin{aligned}
& A_{\mathrm{Ch}}=\left(A_{238 \mathrm{Pu}}-\zeta A_{239+240 \mathrm{Pu}}\right)(\varepsilon-\zeta)^{-1}, \\
& A_{\mathrm{g}}=\left(\varepsilon A_{239+240 \mathrm{Pu}}-A_{238 \mathrm{Pu}}\right)(\varepsilon-\zeta)^{-1} .
\end{aligned}
$$

The percentage of the Chernobyl part in the total activity can be defined as

$$
F=\left[A_{238} \mathrm{Pu}\left(A_{239+240} \mathrm{Pu}\right)^{-1}-\zeta\right](\varepsilon-\zeta)^{-1} 100 \% .
$$

Plutonium activity parts due to the global and Chernobyl fallouts were estimated using $\zeta$ and $\varepsilon$ coefficient values as follows: $\zeta=0.03 \pm 0.01$ and $\varepsilon=0.51 \pm 0.03$ [1]. As a rule, such estimations are related to rather large errors and may be treated as a qualitative characteristic of the sample. Thus, for the same measurement duration, the lower ${ }^{238} \mathrm{Pu}$ activity concentrations in the

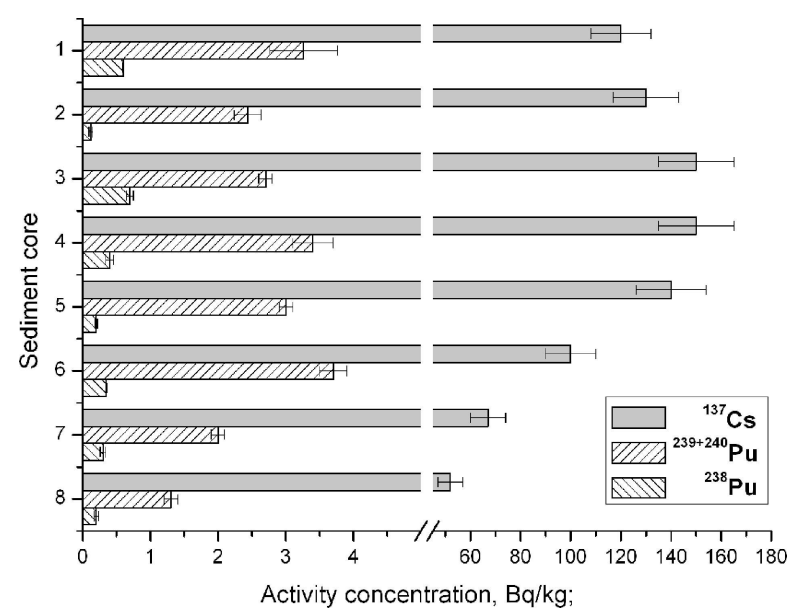

Fig. 2. Vertical profile of ${ }^{137} \mathrm{Cs},{ }^{239+240} \mathrm{Pu}$, and ${ }^{238} \mathrm{Pu}$ activity concentrations in the sediment core (sampling site $B$ ) taken in Lake Žuvintas in 1999/2000 winter.

environmental samples are determined with larger uncertainties than ${ }^{239+240} \mathrm{Pu}$ ones. Moreover, the suggestion on the two main Pu sources of the sample pollution is not always valid. Due to these causes, calculated $F$ values can be sometimes larger than 0.51 . In that case, it was always assumed that the Pu part of the Chernobyl origin in the sample was equal to $100 \%$.

\section{Results}

\subsection{Data on water variables in the lake in winter}

Real conditions in the water column (temperature, $\mathrm{pH}$, conductivity and oxygen, $\mathrm{H}_{2} \mathrm{~S}$ and methane $\left(\mathrm{CH}_{4}\right)$ concentrations) of the southern part of Lake Žuvintas (at large distances from the inflow of the Bambena River) were measured on 14 February 2001 (Table 1).

It is easy to see that under bare ice in February 2001 due to the photosynthetic activity of bottom plants the near-bottom waters in Lake Žuvintas were well oxygenated in spite of rather long distances of the measurement sites from the inflow of the Bambena River - the main source of the outdoor oxygen of lake water in winter. In the near-bottom water, zero $\mathrm{H}_{2} \mathrm{~S}$ concentrations were measured.

\subsection{Pu isotope activity concentration in sediments}

Data on the vertical profile of ${ }^{239+240} \mathrm{Pu}$ and ${ }^{238} \mathrm{Pu}$ activity concentrations in the sediment core taken in Lake Žuvintas in 1999/2000 winter are presented in Fig. 2.

A number of studies [20-23] have shown that such profile of vertical distribution of many radionuclides 
Table 1. Data of the measurements of water variables (temperature, $T ; \mathrm{pH}$; conductivity, $C$; oxygen, $\mathrm{O}_{2}$ ) as well as methane $\mathrm{CH}_{4}$ concentrations in Lake Žuvintas on 14 February 2001.

\begin{tabular}{|c|c|c|c|c|c|c|c|c|c|}
\hline \multirow[b]{2}{*}{ Station } & \multicolumn{3}{|c|}{ Surface water } & \multicolumn{6}{|c|}{ Near-bottom water } \\
\hline & $T,{ }^{\circ} \mathrm{C}$ & $\mathrm{pH}$ & $C, \mu \mathrm{S} / \mathrm{cm}$ & Depth, m & $T,{ }^{\circ} \mathrm{C}$ & $\mathrm{pH}$ & $C, \mu \mathrm{S} / \mathrm{cm}$ & $\mathrm{O}_{2}, \mathrm{mg} / \mathrm{l}$ & $\mathrm{CH}_{4}, \mathrm{ml} / \mathrm{l}$ \\
\hline$A$ & 2.3 & 7.62 & 381 & 2.5 & 4.5 & 7.45 & 460 & 8.48 & 0.4 \\
\hline$B$ & 2.3 & & & 2.5 & 4.5 & & & 7.20 & 0.1 \\
\hline$C$ & 2.3 & & & 2.5 & 4.5 & & & 8.06 & 0.3 \\
\hline
\end{tabular}

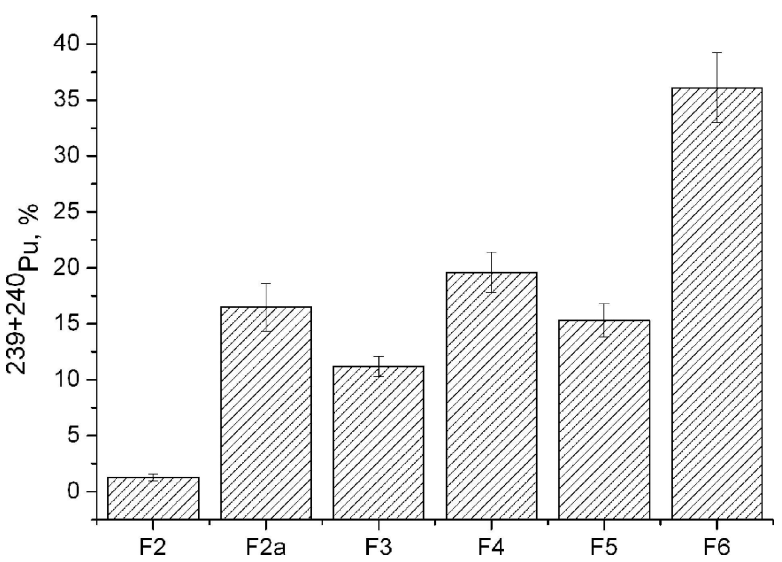

Fig. 3. Distribution of the ${ }^{239+240} \mathrm{Pu}$ activity concentrations in the surface sediments of Lake Žuvintas (sampling site $B$ ) over its physico-chemical forms $(F 2, F 2 a$ exchangeable; $F 3$ bound to organics; $F 4$ bound to carbonates; $F 5$ bound to oxides; $F 6$ lithogenus residue).

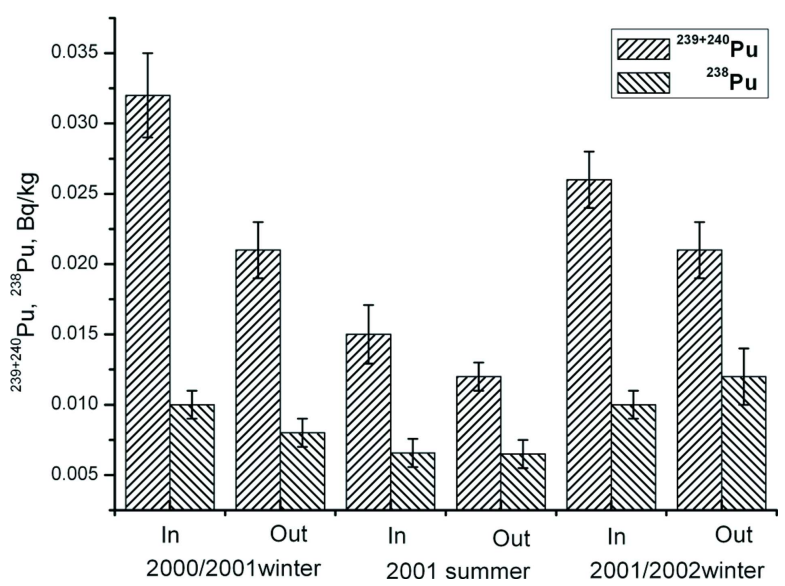

Fig. 4. ${ }^{239+240} \mathrm{Pu}$ and ${ }^{238} \mathrm{Pu}$ activity concentrations in water samples of the Bambena (inflow) and Dovine (outflow) Rivers in 2000/2002.

in the sediments is specific to the lakes with organicsrich bottom sediments. Vertical profiles of ${ }^{137} \mathrm{Cs}$ and ${ }^{239+240} \mathrm{Pu}$ activity concentrations in the sediment core (Fig. 2) show Pu to be more mobile in the sediments under appropriate conditions. Thus, a decrease in ${ }^{137} \mathrm{Cs}$ activity concentrations with the sediment depth begins in the sixth layer (below the $11.1 \mathrm{~cm}$ depth) where ${ }^{239+240} \mathrm{Pu}$ activity concentrations reach their maximum values $(\sim 3.7 \mathrm{~Bq} / \mathrm{kg})$. However, the interaction of plu-

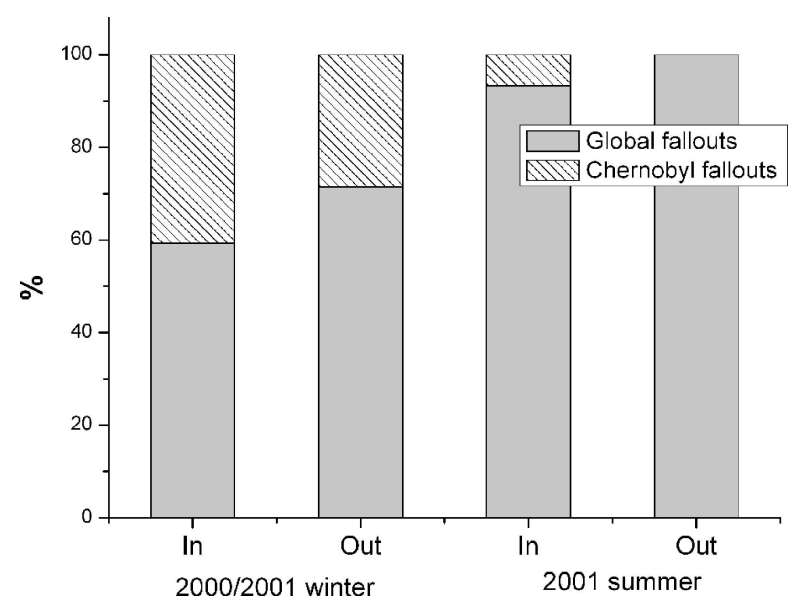

Fig. 5. Distribution of the Pu origin in water running through Lake Žuvintas in different seasons: "in" the Bambena River, "out" the Dovinè River.

tonium ions with organic compounds could considerably affect their mobility because of the formation of stable organic complexes. As mentioned above, the amount of organics in bottom sediments of Lake Žuvintas is up to $67 \%$ [2]. Therefore, the obtained results suggest that processes of accumulation and sedimentation have determined the formation of vertical profile of plutonium in bottom sediments of Lake Žuvintas. The growth of a sediment layer is conditioned by a small depth, regime of temperature, and also biological productivity of Lake Žuvintas. The properties of hydrodynamics of water body and the bulk of suspended matter caused formation of a high-powered accumulation zone in the bottom of lake.

Some causes of rather strong accumulation of Pu isotopes can be established studying the physico-chemical forms of the nuclide (Fig. 3). They must explain that the method of sequential extraction described by Tessier [18] enables the geochemical phases to be separated from each other. The process of operationally defined selective dissolution of macro-scale geochemical components of solid-phase matrix materials allows assessing the geochemical phases of contaminants [24].

It is easy to see from Fig. 3 that the ${ }^{239+240} \mathrm{Pu}$ activity concentration in its total exchangeable fraction $(F 2 a)$ reaches $\sim 15.7 \%$ of the total activity. The potentially mobile fractions $(F 3-F 5)$ of the ${ }^{239+240} \mathrm{Pu}$ activity con- 
centrations (a sum of ${ }^{239+240} \mathrm{Pu}$ activity concentrations bound to organics, to carbonates, and iron and manganese oxides) amount to $42 \%$. A significant amount of ${ }^{239+240} \mathrm{Pu}$ activity concentrations ( $\sim 36.1 \%$ of the total activity) remained in the residual lithogenous fraction (F6), which shows a tenuous migration abilities of plutonium under tested conditions. Overall, a residual fraction of ${ }^{239+240} \mathrm{Pu}$ activity concentration in the sediment layer is comparatively small. Such fractions of ${ }^{137} \mathrm{Cs}$ activity concentrations are always significantly larger [2].

\subsection{On the Pu isotope balance in the lake}

Data on water-soluble ${ }^{239+240} \mathrm{Pu}$ and ${ }^{238} \mathrm{Pu}$ activity concentrations in water samples of the Bambena and Dovine Rivers taken in 2000/2001 winter, 2001 summer, and 2001/2002 winter are presented in Fig. 4. These data show that the activity concentrations of water-soluble $\mathrm{Pu}$ isotopes are the highest in winter. It is easy to see that for both winter and summer season Lake Žuvintas behaves as a Pu accumulator: its activity concentrations in the Dovine River water are always lower than those in the Bambena River.

Therefore, we may suggest that processes of the migration of $\mathrm{Pu}$, which is mainly of the Chernobyl origin (Fig. 5), are related to the existence of anaerobic conditions in the near-bottom water.

Measurement data show that ${ }^{238+240} \mathrm{Pu}$ of the Chernobyl origin is responsible for almost $60-70 \%$ of watersoluble activity concentration of this nuclide in the inflowing water in 2000/2001 winter. In spite of the decrease in the total ${ }^{238+240} \mathrm{Pu}$ water-soluble activity concentration in the Dovine River, the water becomes enriched in $\mathrm{Pu}$ of the Chernobyl origin. In summer 2001, a share of Pu of the Chernobyl origin in its total water-soluble activity in the Bambena River water reaches $\sim 90 \%$. Due to additional enrichment, that share amounts to $\sim 100 \%$ in the Dovine River. Apparently, due to a significant decrease in oxygen concentrations in the water of the Bambena River in its inflow to the lake in winter, insoluble plutonium compounds were deposited earlier. By studying processes of the Dovinè River water enrichment by radiocesium in winter, surface flows were shown to be responsible for low enrichment coefficients [2]. Therefore, after deposition of insoluble plutonium from the water column further water enrichment by $\mathrm{Pu}$ might be possible under anaerobic conditions on account of reduced $\mathrm{Pu}$.

\section{Conclusions}

During the period of the study, bottom sediments of the running shallow Lake Žuvintas behaved mainly as an accumulator of plutonium isotopes. The main part of $\mathrm{Pu}$ of the Chernobyl origin (over 60\%) in surface sediments is presented in exchangeable and potentially mobile physico-chemical forms. Processes of Pu migration are especially active during winter season when under anaerobic conditions the most important role in the $\mathrm{Pu}$ isotope transfer belongs to reduced plutonium ions.

\section{References}

[1] V. Remeikis, R. Gvozdaitè, R. Druteikienè, A. Plukis, N. Tarasiuk, and N. Špirkauskaité, Plutonium and americium in sediments of Lithuanian lakes, Nukleonika 50(2), 61-66 (2005).

[2] N. Tarasiuk, N. Špirkauskaitè, R. Gvozdaite, R. Druteikienè, and B. Lukšienè, Geophysical problems of radiocesium removal from running shallow lakes, Environ. Chem. Phys. 24(2), 45-60 (2002).

[3] E. Koviazina, N. Tarasiukas, R. Druteikienè, and R. Gvozdaite, In situ parametrization of self-cleaning from radiocesium processes in the shallow bottom terrace of Lake Juodis, Environ. Chem. Phys. 25(3), 123128 (2003).

[4] M.J. Keith-Roach, The speciation, stability, solubility and biodegradation of organic co-contaminant radionuclide complexes: A review, Sci. Total Environ. 396, 111 (2008).

[5] K.E. German, E.V. Firsova, V.F. Peretrukhin, T.V. Khyzhnyak, and M. Simonoff, Bioaccumulation of $\mathrm{Tc}, \mathrm{Pu}$, and $\mathrm{Np}$ on bottom sediments in two types of freshwater lakes of the Moscow Oblast, Radiochem. 45, 250-256 (2003).

[6] P. McDonald, J. Vives i Batlle, A. Bousher, A. Whittall, and $\mathrm{N}$. Chambers, The availability of plutonium and americium in Irish Sea sediments for re-dissolution, Sci. Tot. Environ. 267, 109-123 (2001).

[7] M.J. Keith-Roach, J.P. Day, L.K. Fifield, N.D. Bryan, and F.R. Livens, Seasonal variations in interstitial water transuranium element concentrations, Environ. Sci. Technol. 34, 4273-4277 (2000).

[8] Z. Chang, S. Ambe, K. Takahashi, and F. Ambe, A study on the metal binding of humic acid by multitracer technique, Radiochim. Acta 94, 37-46 (2006).

[9] L. Levinskaitė, A. Smirnov, B. Lukšienè, R. Druteikienè, V. Remeikis, and D. Baltrūnas, $\mathrm{Pu}(\mathrm{IV})$ and $\mathrm{Fe}(\mathrm{III})$ accumulation ability of heavy metal-tolerant soil fungi, Nukleonika 54(4), 285-290 (2009).

[10] S. Nagao, Y. Sakamoto, T. Tanaka, and R.R. Rao, Molecular size distribution of Pu in the presence of hu- 
mic substances in river and groundwaters, J. Radioanal.

Nucl. Chem. 273(1), 135-139 (2007).

[11] G.R. Choppin, Actinide speciation in the environment, J. Radioanal. Nucl. Chem. 273(3), 695-703 (2007).

[12] V. Remeikis, A. Plukis, L. Juodis, A. Gudelis, D. Lukauskas, R. Druteikienè, G. Lujanienè, B. Lukšienė, R. Plukienė, and G. Duškesas, Study of the nuclide inventory of operational radioactive waste for the RBMK-1500 reactor, Nucl. Eng. Des. 239(4), 813-818 (2009).

[13] A. Plukis, V. Remeikis, L. Juodis, R. Plukienè, D. Lukauskas, and A. Gudelis, Analysis of nuclide content in Ignalina NPP radioactive waste streams, Lith. J. Phys. 48(4), 375-379 (2008).

[14] I. Klimkaitė, Hydrochemical Characteristics of Lake Žuvintas. The Žuvintas Reserve (The Data of the Expeditions in 1979-1985 (Academia, Vilnius, Lithuania, 1993) [in Russian].

[15] A. Garunkštis and A. Stanaitis, Birth, Development and Death of Lakes (Mintis, Vilnius, Lithuania, 1969) [in Lithuanian].

[16] G. Grižienė, J. Jablonskis, S. Januševičius, I. Jurgelevičienè, A. Jurgelènaitè, A. Juškienè, and R. Kriaučiūnas, Hidrography of the Neris, Energetika 1, 20-41 (1993) [in Lithuanian].

[17] N.A. Talvitie, Radiochemical determination of plutonium in environmental and biological samples by ion exchange, Anal. Chem. 43, 1827-1835 (1971).

[18] A. Tessier, P.G.C. Campbell, and M. Bisson, Sequential extraction procedure for the Speciation of particulate trace metals, Anal. Chem. 51(7), 844-851 (1979).

[19] J.W. Mietelski and B. Was, Plutonium from Chernobyl in Poland, Appl. Radiat. Isot. 46(11), 1203-1211 (1995).

[20] E. Ilus and R. Saxen, Accumulation of Chernobylderived ${ }^{13} \mathrm{Cs}$ in bottom sediments of some Finnish lakes, J. Environ. Radioact. 82, 199-221 (2005).

[21] G. Lithner, H. Borg, J. Ek, E. Fröberg, K. Holm, A.M. Johansson, P. Kärrhage, G. Rosén, and M. Söderström, The turnover of metals in a eutrophic and an oligotrophic lake in Sweden, Ambio 29(4-5), 217-229 (2000).

[22] G.A. Bird and W.G. Evenden, Effect of sediment type, temperature and colloids on the transfer of radionuclides from water to sediment, J. Environ. Radioact. 22(3), 219-242 (1994).

[23] K.H. Lieser and T. Steinkopff, Chemistry of radioactive cesium in the hydrosphere and in the geosphere, Radiochim. Acta 46, 39-47 (1989).

[24] M.K. Schultz, W.C. Burnett, and K.G.W. Inn, Evaluation of a sequential extraction method for determining actinide fractionation in soils and sediments, J. Environ. Radioact. 40(2), 155-174 (1988).

\title{
PLUTONIO IZOTOPAI NEGILAUS PRATAKAUS EŽERO EKOSISTEMOJE
}

\author{
R. Gvozdaitė, R. Druteikienè, N. Tarasiuk, N. Špirkauskaitė \\ Fizikos institutas, Fiziniu ir technologijos mokslu centras, Vilnius, Lietuva
}

\section{Santrauka}

Technogeniniai radionuklidai i vandens sistemas patenka iš atmosferos su iškritomis, nuoplovomis nuo žemès paviršiaus ar su panaudoto branduolinio kuro perdirbimo gamyklų skystais išmetalais. Patekę i vandens telkinius radionuklidai transportuojami per visą vandens sistemą užteršdami ją. Lietuvoje yra virš trijų tūkstančių ežerų, kurių didesnė dalis yra pratakūs ir kartu su i juos įtekančiomis ir iš jų ištekančiomis upemis sudaro vieningą vandens sistemą, kurioje vyksta radionuklidu migracijos, akumuliacijos ir savivalos procesai. Ilgalaikèms prognozèms apie vandens sistemų išsivalymą nuo radioaktyviujų medžiagų sudaryti būtini kompleksiniai radionuklidu elgsenos ir hidrosistemoje vykstančių procesų tyrimai. Tai ypač aktualu sprendžiant radioaktyviujuc atliekų saugojimo problemas uždarius Ignalinos AE.
Pateikti tyrimų Žuvinto ežere, esančiame pietinèje Lietuvoje, patyrusiame globalią branduolinių ginklų bandymų ir Černobylio $\mathrm{AE}$ avarijos radioaktyviają taršą, duomenys. Plutonio izotopu fizinių ir cheminių formų tyrimai ežero dugno nuosėdose parodẻ jų didesni nei ${ }^{137} \mathrm{Cs}$ mobilumą. Černobylio kilmès plutonis paviršiniame dugno nuoseddu sluoksnyje daugiausia yra apykaitinès ir potencialiai mobilios formų. Nustatyta, kad Pu migracijos procesas ežero ekosistemoje ypač suaktyvejja žiemą. Tikriausiai tam turi ịtakos ežere susidarančios anaerobinès sąlygos. Pu izotopų balansas itekančio i ežerą ir ištekančio iš jo vandenyje rodo, kad tokio tipo ežere, kur dugno nuosėdos turi apie $67 \%$ organinès medžiagos, stebimas $\mathrm{Pu}$ izotopu kaupimosi dugno nuoseddose procesas. 